\title{
When Crowd-Based Resources and Capabilities Generates Radical Innovation? It Depends on the Network Effects
}

\author{
Adhi Setyo Santoso
}

President University, Bekasi 17550, Indonesia

\begin{abstract}
A B S T R A C T
Peer-to-peer or digital multi-sided platform (MSP) startups have created disruptions in various industries in the past few years. In this matter, the crowds within the platform ecosystem have significant contribution for digital MSP startups' growth. However, there are limited studies that examine the crowd-based resource and capabilities as the source of radical innovation performance since it still conducts the perspective of linear product-market supply and demand. By using network theory, this research proposal wants to examine the role of network effects toward the development of the radical innovation. The findings of PLS-SEM analysis with 70 respondents from digital MSP startups show that crowds-based resources and capabilities manifested by integrative capabilities can generate radical innovation performance through decent network effect that enables to produce high incremental innovation performance beforehand. It shows the importance interaction between digital MSP startups with the crowds for innovation purposes. Hence, the findings contribute in open innovation literatures especially in finding the contributing factors to generate radical innovation
\end{abstract}

\section{A R T I C L E I N F O}

Article History:

Received : 18-02-2020

Revised : 23-06-2020

Accepted : 23-06-2020

Published : 30-06-2020

Keywords:

Crowd Resources

Peer-To-Peer Platform

Platform Disruption

Incremental Innovation

Radical Innovation

Network Effects

Integrative Capabilities

Multi-Sided Platform

*Corresponding Author E-mail:

adhi.setyo@president.ac.id permits unrestricted use, distribution, and reproduction in any medium, provided the original work is properly cited.

\section{INTRODUCTION}

In the past few years, there are phenomena about the emerging of digital multi-sided platform (MSP) startups that utilizing the crowd resources. These firms offer the "good enough" products or services that can substitute the traditional institutionalbased firms roles. The services are ranging from bank (ex: modalku.com, Investree), hotels (ex: AirBnB, Home Away), transportation (ex: Uber, Grab, Go-Jek), shopping mall (tokopedia.com, bukalapak.com) to labors (ex: sribulancer.com, freelancer, upwork) and many other services. The nature of these MSP firms are decentralization high-impact capital. For example, the operating 
vehicle in Uber are owned by the drivers and rooms used in AirBnB are belong to the hosts. In this case, the firm does not need to provide the capital and operating costs for production goods. Instead, it is converted to relatively small percentage of transaction fees.

The "good enough" products or services of digital MSP startups are blurring the lines between the traditional firm and marketplace platform. The institution-based capitalism has been shifted into crowd-based capitalism (Sundararajan, 2016). Furthermore, crowd-based resources provide more variety of the products and services that leads to more consumption. In some extent, it may change the consumer behavior toward the goods from owning-based perspective to access-based perspective (Lamberton \& Rose, 2012).

Basically, MSP firms are reinventing the new uses of the untapped potential of the existing business practice. They open up excess capacity accelerates the pace of innovation and also organize, simplify and standardize, as well as makes the participation within the platform easier and cheaper (Chase, 2016). Hence, the crowds become micro-entrepreneurs and enjoy greater flexibility and independence. The growth of the MSP firms is also depends on the inclusive growth of the crowd. Therefore, the in digital landscape, the digital trust between digital MSP startups and their member become the prominent issue.

The characteristics of digital MSP startups mentioned above create the platform disruption that disrupt the traditional business in several different ways (Parker, Van Alstyne, Chodary, 2015). First, the digital MSP startups can create new sources of supply where the platforms remove obstacles and, thus, allow more producers to participate in value-creating activities. Second, they can also create new forms of consumer behaviors where platforms encourage users to try products and services. In the innovation literatures, however, this kind of platform disruption has not been examined in a rigorous way. Most of innovation literatures use the perspective of technological or market disruption in a linear product-market supply and demand (Christensen \& Bower, 1997; Christensen and Raynor, 2003; Govindarajan et al., 2011; Adner, 2002). This perspective may be insufficient for explaining the platform disruption since its business model is based on product's ecosystem.

This research wants to fill this theoretical gap by using network theory that common to be used in the economics of IT literatures (Eissenman et al., 2011; Van Alstyne \& Parker, 2005). We will examine the role of the network effects within the crowd for the relationship between integrative capabilities as the manifestation of crowds-based resource and capabilities toward radical innovation as the proxy of potentially disruptive business model. In order to fill the gaps, we raise the research question; when are the crowd-based resources and capabilities generate radical innovation performance? The literature review, theoretical and hypothetical development, variable operationalization, and also concluding remarks will be explained in the next section.

\section{LITERATURE REVIEW}

In order to understand the theoretical foundation of crowd-based resources and capabilities and also search the gap of the previous innovation literatures, we examine the evolution of two developed theory in strategic management area, innovation theory and resource-based theory.

\section{Innovation Theory Evolution}

The innovation theory take the roots of Schumpeterian theory of creative destruction (Schumpeter, 1934), the sharing economy entrepreneurs create the rent by exploiting the opportunity in complex and dynamic environment. It create the rent from disequilibrium condition in the market that, according to the Austrian School of Taught, comes from new resources in production process (Lewin \& Phelan, 2000). This concept leads to two well-known types of innovation; Incremental innovation and radical innovation. Customer-based strategies focusing on manifest needs and the most common innovation 
are associated with incremental innovation (Atuahene-Gima 2005; Han et al. 2012). On the other hand, the fundamental change in new products / services that mark revolutionary product / service benefits is defined as radical innovation (Atuahene-Gima, 2005; Slater et al., 2014). By having this nature, radical innovation is often manifested by potentially disruptive business model that can lead to disruptive innovation afterwards (Govindarajan et al., 2011).

As a cornerstone and foundation of disruptive innovation theory, Christensen \& Bower (1997) raise the concept of disruptive technology that explain "why large firms can be failed?" by examining the disruptor's new technology that interestingly it is inferior compare to the incumbent's technology. However, this disruptor's technologies have simpler, cheaper and more convenient in different performance metrics that will be developed eventually and disrupt the incumbent's technology.

In the next development of disruptive innovation theory, Adner (2002) assess when a new technology has a potential to become a disruptive technology. This research explains about the preference overlap and symmetry from the customer point of view about the different performance metric of the new technology. Christensen \& Raynor (2003) changes the disruptive technology term into disruptive innovation term since the disruption may come form the business model, not the technology. Up until this point, the research of disruptive innovation theory is commonly conducted by qualitative method for longitudinal study. In order to create more established theory of disruptive innovation, Govindarajan \& Kopalle (2005) developed quantitative measurement to assess the potential disruptiveness of any innovation.

Schmidt and Druehl (2008) follow up this study by making a complementary framework for disruptive innovation theory with the encroachment term that explain the disruptive product patterns. The low-end encroachment explains the disruptive innovation type with creating inferior product in the existing market that will diffuses upward eventually. This lowend encroachment is divided into three types. First, the fringe market for new market disruption targets the low-end customers that have incrementally different needs (ex: 5.25 inch disk drive relative to 8 inch drive). Second, the fringemarket for new market disruption targets the low-end customers that have dramatically different needs (ex: cell phone relative to land line phone). Third, the immediate encroachment for low-end disruption targets low-end customers in the existing markets (ex: discount relative to department stores).

Hang et al (2011) also makes another checklist for assessing the potential disruptiveness by extending Govindarajan \& Kopalle previous work. In the further development, Govindarajan, Kopalle \& Dannels (2011) examine the effect of mainstream \& emerging customer orientation on disruptive innovation. The study finds that the firm that have more orientation to emerging customer will be more likely to adopt disruptive innovation. Start from 2015, there are emerging research who assess the disruptive innovation within the platform business mode. Ansari et al., (2015) mention the needs to do the coopetition with the incumbent in Internet television business model since the disruption also disrupt the ecosystem. Laurell \& Sandstorm (2016) mention another source of disruption, institutional disruption, in the Uber platform. Lastly, Parry \& Kawakami (2016) examine the encroachment speed of the e-reader product with incorporating indirect network externalities concept, product complementary.

\section{Resource-Based Theory Evolution}

The roots of current resource-based theory start from the growth of the firm because of slack resources (Penrose, 1959). In the introduction stage of resource-based view, Wernerfelt (1984) mention about the attention to the resources rather than the commercial final products. Barney (1991) develop the antecedents of competitive advantage is by having valuable, rare, inimitable, 
and non-substitutable resources. In the growth stage, Kogut \& Zander (1992) mention that the knowledge of the organization is categorized as the resource. Later, Amit \& Schoemaker (1993) split the resource and capabilities. The capabilities itself is built from the knowledge. Then, Teece et al., (1997) state that the determinant of competitive advantage is a dynamic capabilities, not the VRIO resources anymore.

The maturity stage of resource-based theory is started by the critics from Priem \& Butler (2001) about the usefulness of RBV since this concept does not explain about how to get the resources. Ireland et al., (2003) answer this critics by developing strategic entrepreneurship concept that explain how the organization can discover the opportunity, manage the resource strategically, and also developing innovation that leads to competitive advantage and wealth creation. Alvarez \& Barney (2007) also strengthen the strategic entrepreneurship concept by introducing discovery and creation theory for enacting the entrepreneurial opportunities. 10 years after introducing the concept of dynamic capabilities, Teece (2007) enhance the concept by raising the microfoundation of dynamic capabilities in open economy for invention, innovation, and capabilities resources. The resource orchestration concept by Sirmon (2011) that combine resource management and asset orchestration that explain how organization can transform the resources to enact the environment and develop the capability that will be used for achieving competitive advantage remark the maturity of resource-based view to become resource-based theory. In digital MSP startups context, the dynamic capabilities are embodied in integrative capabilities that is a manifestation from crowds-based resources and capabilities to orchestrate the crowds within the platform ecosystem as source for innovation and firm growth (Helfath and Raubitscheck, 2018).

\section{RESEARCH METHOD}

\section{Hypothesis Development}

In the previous innovation research, the emerging customer orientation tends to put the organization to pursue disruptive trajectory (Govindarajan et al., 2011). Digital MSP startups has unique characteristic by having two-or-more sided market within their platform. Some of them will become suppliers and the others will become buyers. Contrary to the traditional business model that commonly focus on mainstream customers, because of this characteristics, MSP firms often convert the non-consumer in traditional business to become the customers or the suppliers within their platform. This situation is consistent with Christensen (2003) new market disruption topics. Digital MSP startups that able to secure high amount crowd-resources to become the supplier side of the platform will have the huge amount of slack resources. For the digital MSP startups, it is not easy to acquire crowd-based resources. The supplier will join the platform when there are many buyers and vice versa (Eisenmann, 2006). The role of network effect becomes prominent because of this issue. This condition can be achieved when the digital MSP startups has decent integrative capabilities as the manifestation of crowd-based resources and capabilities. Therefore, those concepts can be formalized into hypothesis 1 as follow:

H1: Integrative capabilities has positive association oward the network effects

According to the classic Penrose (1959) theory, the slack of resources will provide the growth of the firm because it can do more things compare to the firm that has limited resources. In digital MSP startups case, these resources developed from integrative capabilities can produce incremental innovation that focus on existing customer needs as well as radical innovation performance in term of introducing new business model that contribute into digital MSP startups engine growth. Therefore, those concepts can be formalized into hypothesis 1 as follow:

H2: Integrative capabilities has positive Association toward the incremental innovation performance

H3: Integrative capabilities has positive association toward the radical innovation 
performance

The network effects consist of direct and indirect types. Direct network effects means the value of the product will be higher when there are more user use that product (Katz \& Saphiro, 1985; Farrell \& Saloner, 1985). On the other hand, indirect network effects can enhance the value of the products when one side or the complementary side of the platform attracts another side of the platform (Eisenmann, 2011; Van Alstyne \& Parker, 2005). In the previous research, the indirect effect of the complementary product influences the encroachment speed of the disruptive technology (Parry \& Kawakami, 2016). Hence, the huge amount of crowd-based resources as suppliers of the MSP firms as disruptors may leads into high encroachment speed since it also provide the indirect network effects as complementary product (Parry \& Kawakami, 2016). Thus, the encroachment speed of the MSP firms may be influenced by the interaction of crowd-based resources and potential disruptive business model adoption. It leads into both incremental innovation performance and radical innovation performance. Thus, those concepts can be formalized into hypothesis 4 and 5 as follow:

H4: Network effects has positive association toward the incremental innovation performance

H5: Network effects has positive association toward the radical innovation performance

Most of these literatures show that Internet venture growth stage strategies have path dependence on their resource and capabilities. The growth strategies also result different performance. The growth speed of the new Internet firm has prominent role in keeping up the good position in the market since the latecomers may need extra effort catch up the first movers (Guo et al., 2016). In the innovation theory setting, the growth of the MSP firms can be a path dependence of the encroachment speed of the radical innovation effort since their early customers may come from the incumbent's or non- direct customer. This condition requires the digital MSP startups to move beyond incremental innovation into radical innovation. However, this effort mostly can be implemented after the firms have decent growth from incremental innovation since radical innovation is often produced as the result of radical adjustment from incremental innovation (Govindarajan et al., 2011). Therefore, those concepts can be formalized into hypothesis 6 as follow:

H6: Incremental innovation performance has positive association toward the radical innovation performance

\section{Procedure}

In order to examine the radical innovation process in the digital MSP startups, the we choose the personnel of founding team, either founder or managers who have decision-making roles, as sample respondents. In order to avoid the bias that might be developed from the members previous experience, we limit the digital MSP startups that consists of young people with a few experiences in creating ventures or managing firms. According to Guo et al., (2016) and Milanov and Fernhaber (2009), the age of new Internet ventures are 10 years or younger. We also choose Indonesia as emerging market context. These contexts have very high market growth as well as high uncertainty due to environmental dynamism. Thus, exploratory learning is needed to overcome the challenge.

Snowball sampling through online and faceto-face survey is conducted to collect the data. We also use self-administrated, questionnairebased quantitative study, to test the hypothesis developed in the previous chapter. The measurement indicators are adapted from the previous study indicators; Dangelico et al. (2013) study for integrative capabilities, Huang (2016) study for network effects, Tien and Cheng (2017) study for incremental innovation performance and radical innovation performance. The Partial Least Square - Structural Equation Modeling (PLSSEM) method is used to analyse the relationship between constructs because of the research 
contexts with small sample and unconfirmed construct relationship. This research analyses the structural model by using bootstrapping sampling technique for inner model, namely path coefficient and t-statistics (p-values), to check the relationship between variables. Furthermore, the outer model is also used to evaluate the validity and reliability of the latent variables (Ringle et al., 2015). Hair et al, (2014) mention that there are certain rules of thumb condition that makes PLS-SEM can be a "Silver Bullet" alternative of Covariance-Based SEM (CB-SEM) when it is difficult to implement because of the assumption criteria cannot be met.

\section{RESULT AND DISCUSSION}

The collected 70 respondents data from digital MSP firms fulfils the criteria of PLS-SEM analysis. As shown in the Figure 1, the research model has three pointed arrows toward the endogenous constructs with R-square 0.453. It fulfils PLS-
SEM criteria that need 59 samples for R-square 0.25 with similar model setting (Hair et al., 2014). The composite reliability of the constructs is above 0.7 that fulfil the internal consistency reliability. All of the average variance extracted (AVE) values are above 0.49 that fulfil the criteria of convergent validity. The variance inflation factor for each indicator is also below 5 that fulfil the threshold of multicolinearity criteria. The loading factor values are presented in the Table 1. The average variance extracted (AVE), composite reliability (CR), mean, and standard deviation are also presented.

The AVE value itself is also greater than the construct's higher squared correlation between the associated construct and other construct that fulfil the discriminant validity criteria. Furthermore, the cross loading table in Table 2 shows that the value of the associated construct is higher than those for the other construct.

Table 1. Instrument Indicators

\begin{tabular}{|c|c|c|c|c|c|}
\hline Items & AVE & CR & SLF & Mean & Std. Dev \\
\hline Integrative Capabilities & 0.560 & 0.864 & & & \\
\hline $\begin{array}{l}\text { 1. The intensity of collaborations for innovation } \\
\text { purposes (ICS1) }\end{array}$ & & & 0.737 & 5.24 & 0.71 \\
\hline $\begin{array}{l}\text { 2. The intensity of information used for innovation } \\
\text { purposes (ICS2) }\end{array}$ & & & 0.692 & 5.26 & 0.74 \\
\hline 3. Acquired new know-how activities (ICS3) & & & 0.706 & 4.97 & 0.82 \\
\hline 4. The intensity of external communication (ICS4) & & & 0.795 & 4.31 & 1.23 \\
\hline $\begin{array}{l}\text { 5. The ability to do high quality external communication } \\
\text { (ICS5) }\end{array}$ & & & 0.804 & 4.34 & 1.27 \\
\hline Network Effect & 0.643 & 0.842 & & & \\
\hline 1. Cross-side network effects (NEF1) & & & 0.838 & 4.76 & 1.10 \\
\hline 2. Same-side network effects (NEF2) & & & 0.873 & 4.79 & 0.81 \\
\hline $\begin{array}{l}\text { 3. Network effects triggered by supporting } \\
\text { partner firms (NEF3) }\end{array}$ & & & 0.681 & 4.23 & 1.36 \\
\hline Incremental Innovation Performance & 0.492 & 0.742 & & & \\
\hline $\begin{array}{l}\text { 1. Growth ratio from incremental innovation in the last } \\
\text { three years (INC1) }\end{array}$ & & & 0.661 & 5.13 & 0.90 \\
\hline $\begin{array}{l}\text { 2. Frequently introduce incremental new features, } \\
\text { content varieties, or process into new markets in the } \\
\text { last three years (INC2) }\end{array}$ & & & 0.800 & 5.09 & 0.99 \\
\hline $\begin{array}{l}\text { 3. Introduce more new features, content varieties, or } \\
\text { process than competitors in the last three years (INC3) }\end{array}$ & & & 0.631 & 5.01 & 0.86 \\
\hline Radical Innovation Performance & 0.569 & 0.798 & & & \\
\hline $\begin{array}{l}\text { 1. Growth ratio from radical innovation in the last } \\
\text { three years (RAD1) }\end{array}$ & & & 0.681 & 3.89 & 1.31 \\
\hline $\begin{array}{l}\text { 2. Introduce more new business model than major } \\
\text { competitors in the last three years (RAD2) }\end{array}$ & & & 0.792 & 4.67 & 1.22 \\
\hline $\begin{array}{l}\text { 3. Frequently introduced new business model into } \\
\text { markets that totally new to the firm in the } \\
\text { last three years (RAD3) }\end{array}$ & & & 0.785 & 4.53 & 1.14 \\
\hline
\end{tabular}


The hypothesis testing result of the research model is presented in Figure 1. Integrative capabilities has positive significant relationship toward network effect ( $p$-value $<0.01$ ), however, it does not has positive significant relationship toward both incremental innovation performance $(\mathrm{p}$-value $=0.328)$ and radical innovation performance $(\mathrm{p}$-value $=0.8)$. Therefore, hypothesis 1 is supported while hypothesis 2 and hypothesis 3 are not supported. Network effect has positive significant relationship toward incremental innovation performance ( $\mathrm{p}$-value $<0.05$ ) but it does not have significant relationship toward radical innovation performance ( $\mathrm{p}$-value $=0.363$ ). It suggests that hypothesis 4 is supported while hypothesis 5 is not supported. Finally, incremental innovation performance has significant positive relationship toward radical innovation performance (p-value < 0.01) that support hypothesis 6.

Table 2. Cross-Loading

\begin{tabular}{lcccc}
\hline & Integrative Capabilities & Network Effect & Incremental Innovation & Radical Innovation \\
\hline ICS1 & $\mathbf{0 , 5 1 2}$ & 0,201 & 0,150 & 0,117 \\
\hline ICS2 & $\mathbf{0 , 4 8 1}$ & 0,218 & 0,147 & 0,089 \\
\hline ICS3 & $\mathbf{0 , 4 9 0}$ & 0,272 & 0,143 & 0,088 \\
\hline ICS4 & $\mathbf{0 , 5 5 2}$ & 0,228 & 0,095 & 0,128 \\
\hline ICS5 & $\mathbf{0 , 5 5 8}$ & 0,284 & 0,128 & 0,170 \\
\hline NEF1 & 0,303 & $\mathbf{0 , 5 8 2}$ & 0,258 \\
\hline NEF2 & 0,269 & $\mathbf{0 , 6 0 6}$ & 0,104 & 0,089 \\
\hline NEF3 & 0,210 & $\mathbf{0 , 4 7 3}$ & 0,248 & 0,369 \\
\hline INC1 & 0,037 & 0,074 & 0,193 & $\mathbf{0 , 4 5 9}$ \\
\hline INC2 & 0,263 & 0,199 & $\mathbf{0 , 5 5 6}$ & $\mathbf{0 , 4 3 3 9}$ \\
\hline INC3 & 0,085 & 0,210 & 0,366 & 0,288 \\
\hline RAD1 & 0,049 & 0,216 & 0,340 & $\mathbf{0 , 4 7 3}$ \\
\hline RAD2 & 0,197 & 0,186 & 0,359 & $\mathbf{0 , 5 5 0}$ \\
\hline RAD3 & 0,154 & 0,116 & $\mathbf{0 , 5 4 5}$ \\
\hline
\end{tabular}

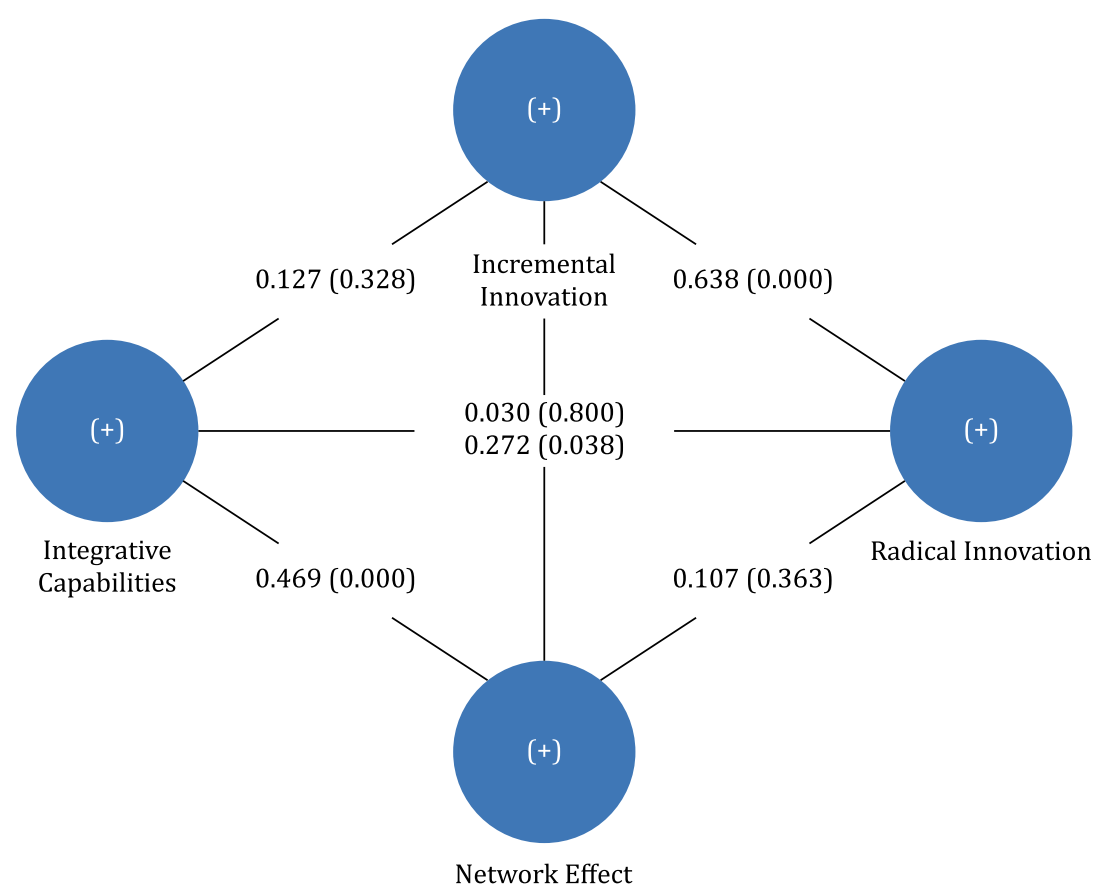

Figure 1. Hypothesis Testing Result 
The hypothesis testing result shows the path for digital MSP startups to generate the radical innovation performance from crowd-based resource and capabilities. The crowd-based resourced and capabilities manifested by integrative capabilities develop the positive network effect triggered by the interaction of the digital MSP startups and the crowds. In this case, the data in Figure 1 shows that digital MSP startups have high coordination capabilities for innovation purposes (ICS1 and ICS2). In digital MSP startups context, the value of business model is created by the integration of supply and demand of multi-sided markets.

coordination capabilities of the digital MSP startups develop the positive network effect between those market, either same-side or crossside markets, due to the digital MSP startups understanding of each market positioning within the business model. It is relevant with Helfat and Raubitscheck (2018) proposition regarding the role of integrative capabilities in strengthen positive network effects that can increase value creation. In fact, a large extent of digital MSP startups value creation comes from the crowds.

The positive network effect between the digital platform ecosystem members means when the number of buyer-side users increases, the number and value of supplier-side users (cross-side) and the number and value of other buyer-side users (same-side) also increase. This situation with the large source of resources, ideas and knowledge triggers the digital MSP startups to generate incremental innovation performance through frequently introduce incremental new features, content varieties, or process into new markets since they have better understanding in existing business model with larger user base. It is inline with Winter (2012) studies that mention network effects determine new product success. In this case, the network effects increase the product advantage and reduce customer uncertainty as the stimuli of market performance.

The incremental innovation performance also performs as the partial mediator between network effect and radical innovation performance with Variance Account For (VAF) value 0.618. The finding exhibits that positive network effect cannot solely produce radical innovation performance such as introducing new business models within the platform ecosystem. The digital MSP startups need to have decent incremental innovation performance to generate radical innovation performance. In the platform ecosystem perspective, the new features, content varieties, or process introduced into new markets can open up the opportunities of new business models creation. During this phase, the digital MSP startups also receive knowledge, ideas, or resources inputs from buyer-side users, supplierside users, or supporting partner firms that cannot be fulfilled or executed perfectly with current business model, especially when the inputs are related with new markets. When the decent incremental innovation performance has been achieved, the digital MSP startups have enough resources to experiment and introduce new business model based on those knowledge, ideas or resources as the manifestation of radical innovation performance.

This situation explains the current phenomenon of digital MSP startups that keep changing or adding their business model overtime. This illustration is strengthen Garcia-Gutierrez and Martines-Borreguero (2016) findings about how startups identifying alternative uses of their innovation. In digital MSP startups context, extending the business models that involving digital platform ecosystem members can be done efficiently through Open API (Application Programmable Interfaces) exchange between platform and the crowds (Aitamurto and Lewis ,2012). Generally, the new business models that generate radical innovation performance is developed and radically changed from the existing business models that produce decent incremental innovation performance. The new category of buyer-side users, supplier-side users, or even supporting partner firms are heavily involved through the new features or Open API exchanges. 


\section{CONCLUSION}

The findings of this study answer the research question regarding when the crowd-based resources and capabilities generates radical innovation performance. The path analysis shows that crowds-based resources and capabilities manifested by integrative capabilities can generate radical innovation performance through decent network effect that enables to produce high incremental innovation performance beforehand. It shows the importance interaction between digital MSP startups with the crowds for innovation purposes. Thus, the findings contribute in open innovation literatures especially in finding the contributing factors to generate radical innovation (Cheng et al., 2016). The unique context of digital platform ecosystem where the crowds have both roles as the users and innovators provide the understanding of the open innovation process. Furthermore, the contribution from this research can be useful for enhance the understanding of the platform disruption in the developing countries that has high population and relatively low GDP per capita since the crowd-based resources will be pretty high in this context. Hence, network effects may also take the significant roles for determining the disruption performance of the new ventures that can be the direction of future research.

\section{RE F EREN C E S}

Adner, R. (2002). When are technologies disruptive? A demand-based view of the emergence of competition. Strategic Management Journal, 23(8), 667-688.

Aitamurto, T., \& Lewis, S. C. (2013). Open innovation in digital journalism: Examining the impact of Open APIs at four news organizations. new media \& society, 15(2), 314-331.

Alvarez, S. A., \& Barney, J. B. (2007). Discovery and creation: Alternative theories of entrepreneurial action. Strategic entrepreneurship journal, 1(1-2), 11-26.

Amit, R., \& Schoemaker, P. J. (1993). Strategic assets and organizational rent. Strategic management journal, 14(1), 33-46.

Ansari, S. S., Garud, R., \& Kumaraswamy, A. (2015). The disruptor's dilemma: TiVo and the US television ecosystem. Strategic Management Journal.

Barney, J. (1991). Firm resources and sustained competitive advantage. Journal of management, 17(1), 99120.

Batjargal, B., Hitt, M. A., Tsui, A. S., Arregle, J. L., Webb, J. W., \& Miller, T. L. (2013). Institutional polycentrism, entrepreneurs' social networks, and new venture growth. Academy of Management Journal, 56(4), 1024-1049.

Batjargal, B. (2007). Internet entrepreneurship: Social capital, human capital, and performance of Internet ventures in China. Research policy, 36(5), 605-618.

Batjargal, B. \& Liu, M. (2004). Entrepreneur's access to private equity in China: The role of social capital. Organization Science, 15, 159-172.

Batjargal, B. (2003). Social capital and entrepreneurial performance in Russia: A longitudinal study. Organization Studies, 24, 535-556.

Chang, S. J. (2004). Venture capital financing, strategic alliances, and the initial public offerings of Internet startups. Journal of Business Venturing,19(5), 721-741.

Chase, R. (2015). Peers Inc: how people and platforms are inventing the collaborative economy and reinventing capitalism. PublicAffairs.

Cheng, C. C., Yang, C., \& Sheu, C. (2016). Effects of open innovation and knowledge-based dynamic capabilities on radical innovation: An empirical study. Journal of Engineering and Technology Management, 41, 79-91. 
Christensen CM, Raynor ME. 2003. The Innovator's Solution: Creating and Sustaining Successful Growth. Harvard Business Press: Boston, MA.

Christensen CM. 1997. The Innovator's Dilemma: When New Technologies Cause Great Firms To Fail. Harvard Business Press: Boston, MA.

Dangelico, R. M., Pontrandolfo, P., \& Pujari, D. (2013). Developing sustainable new products in the textile and upholstered furniture industries: Role of external integrative capabilities. Journal of Product Innovation Management, 30(4), 642-658.

Eisenmann, T., Parker, G. and Van Alstyne, M. (2011), Platform envelopment. Strat. Mgmt. J., 32: 1270-1285. doi: $10.1002 /$ smj.935

Eisenmann, T., Parker, G., \& van Alstyne, M. W. (2009). Opening platforms: How, when and why? In A. Gawer (Ed.), Platforms, markets and innovation. Cheltenham, UK: Edward Elgar Publishing.

Eisenmann, T. R. (2006). Internet companies' growth strategies: determinants of investment intensity and long-term performance. Strategic Management Journal, 27(12), 1183-1204.

Eisenmann, T., Parker, G., \& Van Alstyne, M. W. (2006). Strategies for two-sided markets. Harvard business review, 84(10), 92.

García-Gutiérrez, I., \& Martínez-Borreguero, F. J. (2016). The Innovation Pivot Framework: Fostering Business Model Innovation in Startups: A new tool helps entrepreneurs design business models by identifying the sources of competitive advantage embedded in an innovation. Research-Technology Management, 59(5), 48-56.

Guo, H., Su, Z., \& Ahlstrom, D. (2016). Business model innovation: The effects of exploratory orientation, opportunity recognition, and entrepreneurial bricolage in an emerging economy. Asia Pacific Journal of Management, 33(2), 533-549.

Govindarajan, V., Kopalle, P. K., \& Danneels, E. (2011). The effects of mainstream and emerging customer orientations on radical and disruptive innovations. Journal of Product Innovation Management, 28(s1), 121-132.

Govindarajan, V., \& Kopalle, P. K. (2006). Disruptiveness of innovations: measurement and an assessment of reliability and validity. Strategic Management Journal, 27(2), 189-199.

Guo, R., Cai, L., \& Zhang, W. (2016). Effectuation and causation in new internet venture growth: The mediating effect of resource bundling strategy.Internet Research, 26(2), 460-483.

Hang, C. C., Chen, J., \& Yu, D. (2011). An assessment framework for disruptive innovation. foresight, 13(5), 4-13.

Hair Jr, J. F., Sarstedt, M., Hopkins, L., \& Kuppelwieser, V. G. (2014). Partial least squares structural equation modeling (PLS-SEM). European Business Review, 26(2), 106-121.

Helfat, C. E., \& Raubitschek, R. S. (2018). Dynamic and integrative capabilities for profiting from innovation in digital platform-based ecosystems. Research Policy, 47(8), 1391-1399.

Huang, H. C. (2016). Freemium business model: construct development and measurement validation. Internet Research: Electronic Networking Applications and Policy, 26(3), 604-625.

Ireland, R. D., Hitt, M. A., \& Sirmon, D. G. (2003). A model of strategic entrepreneurship: The construct and its dimensions. Journal of management, 29(6), 963-989.

Kogut, B., \& Zander, U. (1992). Knowledge of the firm, combinative capabilities, and the replication of technology. Organization science, 3(3), 383-397.

Lamberton, C. P., \& Rose, R. L. (2012). When is ours better than mine? A framework for understanding and altering participation in commercial sharing systems. Journal of Marketing, 76(4), 109-125.

Laurell, C., \& Sandström, C. (2016). ANALYSING UBER IN SOCIAL MEDIA-DISRUPTIVE TECHNOLOGY OR INSTITUTIONAL DISRUPTION?. International Journal of Innovation Management, 1640013.

Parker, G., Van Alstyne, M., \& Choudary, S. P. (2016). Platform revolution: how networked markets are transforming the economy and how to make them work for you. 
Parker, G. G., \& Van Alstyne, M. W. (2005). Two-sided network effects: A theory of information product design. Management science, 51(10), 1494-1504.

Parry, M. E., \& Kawakami, T. (2016). The Encroachment Speed of Potentially Disruptive Innovations with Indirect Network Externalities: The Case of E-Readers. Journal of Product Innovation Management.

Penrose, E. (1959). The theory of the firm. NY: John Wiley \& Sons.

Priem, R. L., \& Butler, J. E. (2001). Is the resource-based "view" a useful perspective for strategic management research?. Academy of management review, 26(1), 22-40.

Ringle, C. M., Wende, S., and Becker, J. M. (2015). SmartPLS 3. Boenningstedt: SmartPLS GmbH, http:// www.smartpls.com.

Schmidt, G. M., \& Druehl, C. T. (2008). When is a disruptive innovation disruptive?. Journal of Product Innovation Management, 25(4), 347-369.

Schumpeter, J. A. (1934). The theory of economic development: An inquiry into profits, capital, credit, interest, and the business cycle (Vol. 55). Transaction publishers.

Sirmon, D. G., Hitt, M. A., Ireland, R. D., \& Gilbert, B. A. (2011). Resource orchestration to create competitive advantage breadth, depth, and life cycle effects. Journal of Management, 37(5), 1390-1412.

Sundararajan, A. (2016). The Sharing Economy: The End of Employment and the Rise of Crowd-Based Capitalism. MIT Press.

Teece, D. J. (2007). Explicating dynamic capabilities: the nature and microfoundations of (sustainable) enterprise performance. Strategic management journal, 28(13), 1319-1350.

Teece, D. J., Pisano, G., \& Shuen, A. (1997). Dynamic capabilities and strategic management. Strategic management journal, 509-533.

Tien, W. P., \& Cheng, C. C. (2017). Managing online creativity for improving innovation performance. Internet Research.

Wernerfelt, B. (1984). A resource-based view of the firm. Strategic management journal, 5(2), 171-180.

Winter, S. (2012). Network effects and new product success: strengthening product advantage, overcoming customer uncertainty?. International Journal of Business Innovation and Research, 6(1), 1-27.

Zhang, C. B., Li, Y. N., Wu, B., \& Li, D. J. (2016). How WeChat can retain users: Roles of network externalities, social interaction ties, and perceived values in building continuance intention. Computers in Human Behavior. 